\title{
The Limits of Misogyny: Schopenhauer, "On Women"
}

Thomas Grimwood

\section{Introduction: Misogyny and why it Matters ${ }^{1}$}

G

iven that, for the past thirty years or so, there has appeared a seemingly limitless range of approaches to the "problem of woman" in Nietzsche's writing, it is somewhat surprising that his oft-cited philosophical mentor, Arthur Schopenhauer, has largely escaped the same scrupulous attention. Indeed, the idea that Schopenhauer despised women has gone relatively unchallenged in general philosophical literature from around the 1930's onwards. Schopenhauer's role as an "arch-misogynist" serves as an unproblematic background figure or frame of reference to the more unsavoury elements of texts by the likes of Nietzsche, Freud and so on. For example, in Francis Nesbitt Oppel's recent work on Nietzsche, Schopenhauer's texts are cited as a means to interpreting Nietzsche's "misogyny" as ironic: in order to analyse Nietzsche's writing on women as an ironic play on misogyny, there is a need for an "original" misogyny to supply the object of such an irony. Schopenhauer, in brief citation, serves as a ready example of such "original" misogyny, without the need for direct interpretative engagement. ${ }^{2}$

On closer inspection, there remains a notable absence of detailed analysis of Schopenhauer's misogyny, and his infamous essay "On Women."3 Along with his poodle Atma, it is common to find "On Women" as defining a certain caricature of Schopenhauer, but a caricature that would seem of little constructive interest to scholarship. Christopher Janaway's argument that Schopenhauer's views on women hold "no very interesting connection with his philosophy," and D. W. Hamlyn's claim that it is possible to ignore the misogynistic comments of Schopenhauer completely, as they bear no relevance

${ }^{1}$ This research was made possible by the generous funding of the Arts and Humanities Council of the United Kingdom. I would like to thank Arthur Bradley, Alison Stone and Lynne Pearce for their helpful comments on previous versions of this paper. 2005), 146.

2 Francis Nesbitt Oppel, Nietzsche on Gender (London: University of Virginia Press,

3 Arthur Schopenhauer, Parerga and Paralipomena Vol. II, trans. by E. J. Payne (Oxford: Clarendon Press, 1974), hereafter PPII; I will refer to Payne's translation, although the section numbers correspond to Arthur Hübscher's German edition Sämtliche Werke, $4^{\text {th }}$ ed. (Mannheim: F.A. Brockhaus, 1988).

4 Christopher Janaway, "Introduction," in The Cambridge Companion to Schopenhauer (Cambridge: Cambridge University Press, 1999), 1-17, 15. 


\section{THE LIMITS OF MISOGYNY}

to the "system," 5 are representative of a general lack of interest in the essay. Unlike the plethora of writings on Nietzsche's treatment of women, it has been common to treat "On Women" as an avoidable and somewhat regrettable text on behalf of the Schopenhauer scholar, a present day embarrassment, much in the same way that a good deal of his scientific offerings are now officially "dated."

This exegetical gap is surprising for two reasons. From an external analysis, the frequency by which Schopenhauer is referred to in Nietzsche scholarship as the misogynistic "horizon" against which Nietzsche's views should be assessed suggests that a more comprehensive account of when, why, and how Schopenhauer's philosophy is anti-women. From an internal analysis of Schopenhauer's philosophy, the recurrence of the criticism that Schopenhauer's philosophical system does not pay sufficient attention to the possibility of alternative subject positions, ${ }^{6}$ suggests that this overlooking of "On Women" is particularly significant. It is, after all, a rare example of Schopenhauer approaching the issue of the "Other," and the possibilities of a 'subject position" outside of the authorial narrative.

In short, when Schopenhauer's misogyny is presumed or ignored, a serious theoretical account of Schopenhauer's philosophy of woman-and, by extension, Nietzsche's (and others) relation to Schopenhauer's misogynyseems unlikely. Indeed, when a more significant amount of time is taken over the problem of "woman" in Schopenhauer's work, and "On Women" in particular, a more complex picture arises. ${ }^{7}$ For some years now, Angelika Hübscher's 1977 paper 'schopenhauer und die Weiber" has stood as one of the few detailed analyses of the essay. Hübscher argues that the notion of Schopenhauer as a misogynist arose not from primary accounts of his life, but rather through the regurgitation within secondary literature of unsupported generalisations made by writers who never knew Schopenhauer in person. ${ }^{8}$ As a result, interpretations of "On Women" have suffered from certain misreadings which perpetuate Schopenhauer's status as a misogynist. Against this popular image, she presents a reading of Schopenhauer as a philosopher who was capable of love and attachment, and who did not "hate" women in the way he has often been portrayed. In this sense, Hübscher argues that "On Women" is an attempt to re-instate a more "classical" view of women, in opposition to the "romantic." Indeed, she points out that at points Schopenhauer appears to reserve the highest attributes of humanity for both men and women, and there is thus no proof that he was an out and out frauenhasser. $^{9}$

\footnotetext{
${ }^{5}$ D. W. Hamlyn, Schopenhauer (London: Routledge \& Kegan Paul Ltd., 1980), 156.

${ }^{6} \mathrm{I}$ do not have the space to elaborate on this problematic in more detail; see J. Atwell, Schopenhauer on the Character of the World (London, University of California Press, 1995), 94-98 for a more in-depth discussion.

7 A. Hübscher, 'schopenhauer und die Weiber," in Schopenhauer Jabrbuch (1977), $187-$ 203.

8 Ibid., 187-8.

${ }^{9}$ Ibid, 199.
} 
In this paper, I intend to re-open these questions over Schopenhauer's misogyny which Hübscher raises. While I agree with Hübscher that "On Women" should not be dismissed as unsystematic and irrational, I disagree with her reading on several key points. Thus, I will re-present Hübscher's reading of the text in parallel with my own interpretation, in order to raise some key interpretative issues Schopenhauer's essay raises. Unlike Hübscher, it is not my aim to "defend" or "rescue" Schopenhauer from the charges of misogyny. While Hübscher aims to rationalise Schopenhauer's statements on women in a more thoughtful and complimentary light, my reading shows the rhetorical structure of his argument as systematic. In doing so, my aim is to understand Schopenhauer's misogyny as a philosophical argument in order, first, to clarify the ways in which his philosophy limits the status of women as an economic subject, and second, to demonstrate the fundamental and intriguing weakness to this argument. In doing this, I hope to show that Schopenhauer's misogyny is more sophisticated and structured than has previously been thought, but also that there exist certain problems with this structure.

\section{Reading Misogyny: The Question of Approach}

Just what sort of text is "On Women"? It would seem that the main explanation for the lack of close analysis of "On Women" is that the essay operates more as an opinionated detailing of Schopenhauer's attitude to women, and, for that matter, has no place in his systematic thinking. The text is fragmented, a style which often gives a text an unsystematic appearance (certain parallels with Nietzsche interpretation can be made here). The apparently anecdotal basis of the essay has often led to Schopenhauer's argument being viewed as contextually limited (not to mention debatable), ${ }^{10}$ and bears little relevance to our reading today. Categorising the essay as a mere historical "description" simultaneously legitimises Schopenhauer's work as "readable" in the present day, yet also renders the arguments of the essay illegitimate without paying their workings too much attention; it is merely a less than balanced view of women at the time.

This approach would be valid if our interest was limited to a purely historical reconstruction. However, Hübscher points out, quite rightly, that an historical approach risks enforcing an unfounded prejudice over Schopenhauer's intentions, a tradition built from initially ungrounded assumptions over the nature of the "On Women" which are, in turn, repeated in secondary literature without question. For example, Hübscher notes that

10 This reaction can be found as far back as Helen Zimmern's writing in the nineteenth century, who claimed that amid the rampant misogyny of the piece "are acute and profound remarks on the undeniably weak points in the female character such as women's habitual disregard of abstract justice, and lack of consideration for inferiors," whilst pointing out that Schopenhauer was never actually acquainted with intellectual women who would disprove his theory that denied the possibility of genius to women. See Arthur Schopenhauer: His Life and Philosophy (London, Longmann Green \& Co., 1876), 228. 


\section{THE LIMITS OF MISOGYNY}

while Schopenhauer's preferred term for women, die Weiber, is commonly read as a derogatory term for "women" in contemporary German usage, it was only from the 1930's that the word took on a negative meaning, which until then was a non-effective description for women. ${ }^{11}$ Indeed, it is noticeable that while we find the earlier commentaries of Helen Zimmern or Thomas Bailey Saunders praising Schopenhauer's authorship for its broad appeal that crosses class and gender in its appeal, ${ }^{12}$ by 1939 Thomas Mann is writing of Schopenhauer as a grotesque tyrant of a figure, with an exaggerated sense of selfhood, illustrated most vividly in terms of sexual impulse. ${ }^{13}$ The shift in interpretative focus on the authorial figure from a philosopher for the general populace to a self-grandiose misogynist roughly at the same time as this is surely more than a coincidence. It would certainly offer a plausible connection between the complimentary way in which Beer declares in 1914 that Schopenhauer was "burdened with abnormally strong desires for the pleasures of life, together with an extraordinary capacity for suffering,"14 and Blüher's conclusion in 1936, from this same "information," that Schopenhauer was unambiguously homoerotic, with a hatred and fear of women that stemmed from feelings of guilt at the death of his father. ${ }^{15}$

For Hübscher, such "information" is often purely hypothetical and speculative, rarely based on any substantial empirical evidence. This said, Hübscher herself seems to rely on sources beyond the actual text of "On Women" to justify her reading. ${ }^{16}$ While such sources may not be as "second hand" as those interpretations she criticises, Hübscher nevertheless gives authority to journal entries and reported incidents which often conflict with (and ultimately override) the more brute "facts" of the text itself. Thus, while I agree that it is wrong to see Schopenhauer as an irrational hater of women, Hübscher's argument that the appearance of misogyny in Schopenhauer's work is due more to translation and cultural change sits ill with statements from "On Women" itself-there can, after all, only be so many ways to translate its persistent and clear claims that women are inferior to men.

While it is true that secondary literature has played a part in demonising Schopenhauer's views on gender, this interpretative context is not simply ignorable when we approach the text of "On Women" today. Rather, these representations of Schopenhauer reflect a concern with the authorial style: that is, the way in which Schopenhauer imposes his authority within his

\footnotetext{
11 Hübscher, op cit., 194.

12 See Zimmern, H., op cit. and Saunders Bailey, Schopenhauer (London: Adam \& Charles Black, 1901).

13 T. Mann, "Presenting Schopenhauer," in Schopenhauer: His Philosophical Achievement (Sussex: The Harvester Press, 1980), 3-19.

${ }_{14}$ M. Beer, Schopenhauer (London: T.C. \& E.C. Jack, 1914), 16.

15 See Hübscher, op cit., 188.

${ }^{16}$ This is, in part, due to her view of Parerga and Paralipomena, the collection of essays which "On Women" is taken from. According to Hübscher, this collection is not as important a text for the systematic understanding of Schopenhauer as The World as Will and Representation, and consequently the "proper" understanding of Schopenhauer's views on women can be found in the chapter "The Metaphysics of Sexual Love" within that work.
} 
own text. To this end, the role of this "authorial effect" in the text's meaning is far more significant, I think, than Hübscher allows. My approach to the text, which I will outline in this paper, begins with the fact that "On Women" is dominated by a rhetorical centrality of the "self" in relation to the external "other." To this extent, the fact that the brevity of reference which we noted earlier is somewhat characteristic of the uses of Schopenhauer in such discussions should not be ignored. What leads the philosopher-figure of Schopenhauer to such an immediate caricature is, simultaneously, what constitutes much of the philosopher's rhetorical strength. After all, in the preface to the first edition of his magnum opus, World as Will and Representation, Schopenhauer declares that all of his work is the elaboration of a 'single thought" (even if, as John Atwell points out, this single doctrine does not always seem to be consistent or systematic). ${ }^{17}$ The working and reworking of this core philosophy which characterises Schopenhauer's life reveals, I would argue, a signature shaped around an irrepressible concern for its own limits; that is to say, the very assertion of his authorship - the assertion of a singular, authorising, meaning of the text - is a continuous inscription of the boundaries of subjectivity. In this sense, "the world is my representation" is Schopenhauer's 'signature piece," to borrow Peggy Kamuf's term;18 underlying this claim is the persistent theme of self-identity within Schopenhauer's rhetoric, whether pitted against the world, other philosophers, or "woman." In other words, the singularity of Schopenhauer's authorial subject is as structural as it is stylistic, and such passing references are not necessarily being unjust to what we might term the 'spirit" of Schopenhauer's corpus.

\section{Woman as a Double Image}

The key to understanding "On Women" as structurally consistent, I would argue, is to begin with this notion of an "authorial subject," and understand this as a singularity which "women" cannot occupy, either morally or economically, as the conclusion of the essay makes clear. While Schopenhauer concludes his study with one reference point- "woman"- his argument in fact employs two distinct and contrasting images of woman within this one reference, which stand in relation to the authorial 'self' occupied by the male subject. It is by developing these two images in contrast to each other that the eventual subordination of "woman" in the spheres of morality and economics becomes philosophically conclusive.

We can outline what these two images of woman correspond to by looking at the opening section of the essay. Here, Schopenhauer refers to three poems on a similar subject by Schiller, Jouy, and Byron. Of these, Schopenhauer claims that the latter two "express the right point of view for the value of women." Schiller's view, while "well-considered," is not adequate for

17 See J. Atwell, Schopenhauer on the Character of the World (London: University of California Press, 1995), 1, 18.

18 See P. Kamuf, Signature Pieces (London: Cornell University Press, 1988). 


\section{THE LIMITS OF MISOGYNY}

praising woman because it "produces its effect by means of antithesis and contrast." 19 What is the difference between the two cases? Schiller's work employs a sense of mythical unity between the sexes: in Würde der Frauen, for example, the violent and wild "man" succumbs to the charm of his opposite "woman," and in doing so produces an ideally balanced relationship. It is not the notion of contrast per se that Schopenhauer objects to, but the use of contrast as a means to expressing woman's value as the dialectical antithesis of man: the notion of the relationship between the sexes as two parts of one "natural" whole (as he declares elsewhere, "conjugal fidelity for the man is artificial"). ${ }^{20}$ In both Byron and Jouy's words, meanwhile, man's birth is an act of the woman, whilst in death woman's consolation is passive. The contrast here is not between an active "man" and a passive "woman," but between two images of "woman."

This idea of contrast creates not one but two different views of woman which develop through the essay, in alternate sections. If we interpret the essay as two images of "woman," rather than one incoherent presentation, it can further be suggested that these two threads correspond in general to an active image in relation to man's subjectivity on the one hand, and on the other as an image of surplus energy in sharp contrast to man's "limit." When placed next to each other, we can see how each section regarding surplus relates specifically to the previous section's activity, and how the activity itself develops from use to surplus. One can see how this double image enables the essay to develop a linear narrative on the value of "woman": her "uses" become more and more displaced from the morally responsible, economically viable subject which "man" occupies (see the figure below).

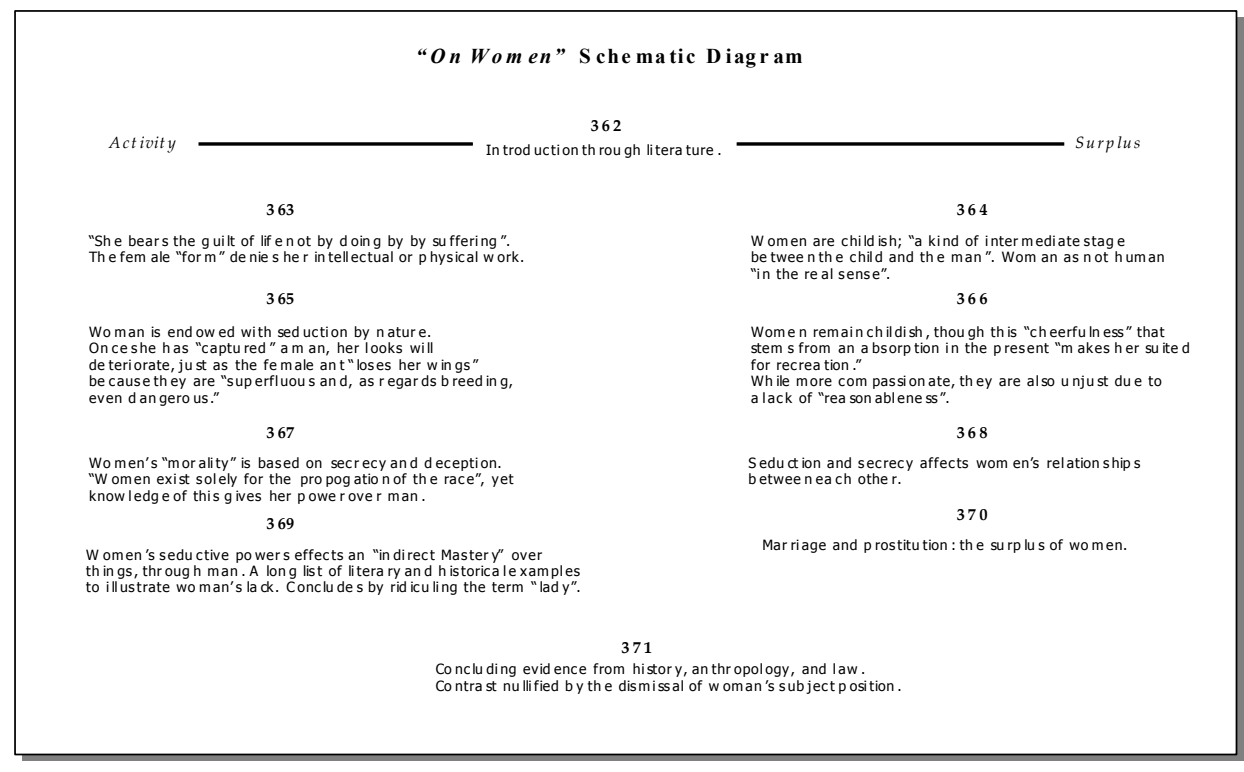

19 PPII, 614.

${ }^{20}$ Schopenhauer, A., The World as Will and Representation Vol. II, trans. by E. J. Payne (New York, Dover Publications Inc., 1969), 542. Hereafter WWII. 
In all cases, Schopenhauer attempts to demonstrate how the negative value of woman undoes the positive value by virtue of its own, vicious, circularity. In other words, Schopenhauer is not arguing that women possess both an active role, on the one hand, and a passive role, on the other; rather, he is attempting to show that accounts of women's agency necessarily leads them to be passive and in the thrall of man. The crux of the text is not, then, a simple dualism between "active" and "passive," but a conceptualising of the more complex relationship between the limited activity of an undeveloped agency and the surplus activity of an unrefined subject. It is precisely this double image of woman as, on the one hand, a nascent pre-subjective character, and on the other, a character who exceeds the subjective limits of a responsible agent, which is the fundamental undercurrent of Schopenhauer's argument.

For example, in \$363, Schopenhauer describes such activities as "the pains of childbirth, care for the child, submissiveness to her husband, to whom she should be a patient and cheerful companion." 21 We might notice that Schopenhauer adopts an imperative on what we might call woman's "ethical" position: she should be patient and cheerful to her husband, and her life should be gentler and milder than the man's, "without being essentially happier or unhappier." \$364, though, offers a different view: women are suited to look after "us" in "our earliest childhood" because they are themselves "childish, trifling and short-sighted." They are "grown-up children."22 This image is sufficiently different to the active suffering of the previous section; now, women's tendency to child-like acting undoes the balance she has been afforded in the previous section. They are categorised as "a kind of intermediate stage between the child and the man, who is a human being in the real sense"; but whereas this may reflects the under-developed subjectivity of woman, it is a ridiculous image. While the first segment demonstrates women's activity in relation to existence, the second demonstrates how such activity surpasses usefulness, and "care for the child" is not an occupational role but rather becomes evidence of women's lack of agency (as Schopenhauer declares, "imagine what a man... could do in her place!").

Women retain a sense of "activity" in one very important sense for Schopenhauer's philosophy of the Will: they hold the power of seduction over men. Zimmern notes that 'schopenhauer, recognising the strength of instinct and keenness of intuition in the female sex, sees in it a closer manifestation of the original cause of being. Woman is but one remove from the "will to live."'"23 This proximity to the will to live is expressed by the tools of seduction which nature has bestowed on women to lure man into marriage. Furthermore, they are tools seemingly for the one aim: Schopenhauer comments that such seductive qualities are lost once marriage is found (this will form the background to his view on the deceptive nature of women; and

\footnotetext{
${ }_{21}$ PPII, 614

22 Ibid., 615.

${ }^{23}$ Zimmern, op cit., 228.
} 


\section{THE LIMITS OF MISOGYNY}

also, his disdain for man's apparent submission to the "unaesthetic sex"). $₫ 366$ counters this by returning to the status of woman as less-than-human. Women develop their full sense of rationality, argues Schopenhauer, at the age of eighteen, and consequently, it is only a "meagre" sense of reason. Woman is thus compared to "the animal" who lives "merely in the present." 24 Hence, what Zimmern had previously identified with a strength of the female sex is now viewed as a denigration of the male form: and, importantly, whilst in the previous section the animalism of woman's seduction suggested some kind of separate species (or subjectivity), here the familiar Aristotelian hierarchy is reinscribed, where man is positioned as higher than woman through his capacity for and use of the intellect. It is not just, then, that women lack "reasonableness"; what Schopenhauer terms the "art of dissimulation" has been given to woman by nature in the same way animals are given weapons of defence. Thus, the alluring seduction of woman that was presented in the previous section develops itself in to the realisation that such deceptive cunning comes at the expense of her legitimacy as an ethical agent: "[A]n entirely truthful and unaffected woman is perhaps impossible." 25 While woman's use of seduction in $\$ 365$ promises a certain subjectivity, or a presubjective state of being-"woman is still the multitude seducing the singularity of the male subject, at this point - the development of this seductive capacity is not to the singular subject position. Rather, the point at which woman is identified as a being "closer to the will" is also the point at which she is figured outside of the boundaries of subjectivity.

The presence of these two images, which are both referenced under the term "woman," does not go unnoticed in Hübscher's reading. She claims that Schopenhauer uses "On Women" to attack, not "woman" in general, but rather Romanticism and its ideas over the human being. In its place, Schopenhauer asserts a more "classical idea" of humanity. Hence, Hübscher argues, Schopenhauer's two images reflect two common ideals of women in $19^{\text {th }}$ century German literature. The first image (Schopenhauer's preferred) is a reflection of the "classical" pre-modern image of woman, whilst the second represents the liberated romanticist image of woman. ${ }^{26}$

Such philosophical critiques of the Romantic view on gender relations are not uncommon-similar appraisals can be found readily in Nietzsche's Human, All Too Human, for example-but nevertheless I have to disagree with Hübscher's claim on this point, chiefly because it does not explain the complexities of Schopenhauer's presentation of woman in relation to "the

${ }^{24}$ PPII, 616-7.

${ }^{25}$ Ibid., 617.

${ }^{26}$ Hübscher, op cit., 193. It would perhaps be tempting to simplify this as an oppressive image against a liberated, or a passive image over an active image, but this would be false. Firstly, the "classical" image of woman is not necessarily passive, but limited in respect to the boundaries of their actions (i.e. within the household), whilst the "liberations" of the Romanticist woman are debatable. But furthermore, as Hübscher makes clear, the popular "classical" image of woman in $19^{\text {th }}$ century Germany was an idealised nostalgic reflection of the classical age. Op cit., 196. 
subject." True, Schopenhauer rarely mentions Romanticism without arguing its inferiority to the classical age. ${ }^{27}$ However, there is no mention of Romanticism by name here, just as there is no consistent presentation of the "classical"; it is also important to note that Schopenhauer's main charge against Romanticism, and in particular Friedrich Schlegel, is chiefly his "obscurantism," rather than his social policy. ${ }^{28}$ Above all, if Hübscher's argument were the case, one might suggest that Schopenhauer would be more successful in his defence of the idealised classical woman. However, in $\$ 369$, his account of the possibility of woman's subjectivity takes an intriguing turn.

\section{Schopenhauer's Use of Authority}

Having established the natural endowments of women, and concluded from this that her "only" role is the propagation of the race, for which she is equipped by nature to seduce and "capture" man, Schopenhauer has simultaneously argued that the exuberance and cheerfulness of women is disruptive and chaotic, and that consequently requires "obedience" to the rational subject is necessary on her part. ${ }^{29}$ By operating outside or beyond the rational subject's limit woman's existence is, correspondingly, a threat; not only to the male subject position (as has been elaborated in \$365 and \$367), but also to woman's agency: $₫ 368$ argues that a woman's drive for success inverts itself against other women, and thus becomes self-defeating.

At this point, then, with two differing images of women developed thus far, a particular culminating point would seem to be necessary here. That point would be the possibilities of a sovereign female subjectivity. One can trace the progression which builds to this point through $\$ 363$, $\$ 365$ and $\$ 367$, by virtue of their relation to the second thread. ${ }^{30}$ And indeed, the section's main target is specifically the veneration of women by men; this reaches its conclusion in Schopenhauer's attack on the "lady"- "for woman... is by no means qualified to be the object of our respect and veneration, to carry her head higher than man and have equal rights with him." 31 In terms of its operative effect on the essay as a whole, $\$ 369$ is perhaps the most important, as it offers grounds for the concluding argument in \$371 that women should have no economic independence, or indeed any independence at all. However, it is also at this point that Schopenhauer's so far methodical play on the contrast of the female form suffers something of a collapse. It is at this point that Schopenhauer, to an extent, retreats from the previous terrain of the essaythat which is intrinsically concerned with woman's relation to the will in nature-to a much less "argued" and much more forceful polemic, relying on

\footnotetext{
27 "Without the school of the ancients, your literature will degenerate into vulgar gossip and flat philistinism." WRII, 124.

28 See, for example, Ibid., 525.

${ }^{29}$ Hence the claim at $\$ 363$ that woman's lot is one of 'suffering."

${ }^{30}$ In $\$ 370$, we find the culminating point of the second thread, where women's excess itself is "contained," by its positioning in relation to man through the medium of marriage.

31 PPII, 622
} 


\section{THE LIMITS OF MISOGYNY}

the authoritative power of other authors to make his point. ${ }^{32}$ This is made all the more interesting by the fact that it is only in this section that such a deferral of authority takes place: in the following section, $\$ 370$, the structural balance found in the rest of the work is restored.

Schopenhauer begins the section by claiming that women have no appreciation of the arts because if the Ancient Greeks "really did not admit women to the play, they were right; at least it would have been possible to hear something in their theatres." 33 The "chatter" of woman is, on the one hand, an effect of her cheerfulness, of her lack of morality and appreciation for the abstract or objective. Such an illustration of women's excess is also a disruptive presence to Schopenhauer's appreciation of the aesthetic; and, in turn, this very discussion leads to the question of woman exceeding her place, taking an equal footing with man, and adopting the title of "lady" - in other words, substantiating a subject-position within society.

Importantly, it is at this point that Schopenhauer refers not to anecdote or his own philosophy, but rather introduces quotes from as wide a field as Huarte, Napoleon I, Chamfort, St. Paul, and Rousseau. These references all imply, in one way or another, a similar view: that to allocate woman a subject-position is unnecessary, the culmination point of "ChristianGermanic stupidity." 34 His strategy runs, in effect, parallel with his (somewhat dubious) claims that women "have never been able to produce a single, really great, genuine and original achievement in the fine arts, or bring to anywhere into the world a work of permanent value." 35 Precisely because women lack the capacity for the intellectual, Schopenhauer relies on intellectual literature for support.

The use of quotations is notable because Schopenhauer only references writers otherwise in the first and last sections of the essay. ${ }^{36}$ But these referrals mark a significant shift in the essay. The notion of contrast that has previously dominated the essay has now shifted its focus. We are no longer looking at the contrast in women themselves-i.e., between the active and the ridiculous - but the contrast between men and women, which, in turn,

32 This is not to say that Schopenhauer is treating these authors as great writers in themselves - his view of both these authors is generally ambivalent, in the case of Rousseau often hostile (e.g. WRII, 532-3). This is also not to say that such an act of referencing is somehow out of keeping with Schopenhauer's writing style, because that would be plainly false (constant referencing, sometimes unfathomably wide, is a hallmark of World as Will and Representation). However, the point is that these references to other authorships and authorities occur at this specific moment in the text. Again, Hübscher's suggestion of a classical/Romanticist dichotomy is also questionable here, given the lack of reference to, or even caricature of, Romanticist literature.

33 PPII, 620

34 Ibid., 621.

35 Hence, he makes a point that Huarte's book "has been famous for three hundred years" (Ibid., 620); he also refers favourably to the Greeks, whose philosophical achievements were long standing. The quote taken from Napoleon presumably indicates the strength necessary for genius.

36 Also, a very brief mention of Thomasius" De concubinatu in \$370 - Schopenhauer only recommends we read this, though, and does not use it for his argument. 
becomes the contrast between art and chatter, thought and thoughtlessness, use and uselessness. Operatively, this section works to rule out any notion of a female subject position. That is to say, at the precise point that woman the two threads threaten to merge in to one account of female subjectivity, this subjectivity is immediately placed in relation to man. And it is precisely here we find, not that woman is a lesser subject of the intellect than man, but an entirely superfluous one. What Schopenhauer has in effect done, is replace a discussion of the possible female subject position with a foreclosing discussion on the impossibility of such a position.

There is, then, something of an authorial recession at the same point he makes his boldest misogynistic claim. At its most misogynistic, "On Women" is not authored by Schopenhauer, for the important reason that Schopenhauer's authorial subject lacks the authority to claim women possess no sovereign subject position at this point. The inscription itself limits this image of woman to a position outside of subjectivity, and not, as has been suggested, an alternative conception of the subject potentially damaging to Schopenhauer's system, only at the expense of the authorial capability itself. The assertion of a limit, asserted through the authorial subject, takes place at the expense of Schopenhauer's own authority, and at the point where authority dissimulates in to a multitude of other reference points.

\section{Economic Exclusion and the Surplus of Women}

Having argued against Hübscher's interpretation on the grounds that such a reading requires Schopenhauer to have been more successful that he has been in his argument, I now face the problem of justifying this "problem" for Schopenhauer's authority in terms of my reading. There must be, in other words, a structural necessity to $\$ 369$ which forces Schopenhauer's hand. We can see this necessity more clearly from examining the way in which the essay places limits on woman's economic sovereignty.

When $\$ 370$ brings up the issue of prostitution and its relation to woman's existential situation, this image arises from two sources. On the one hand, it is for Schopenhauer perhaps the ultimate illustration of the surplus of women, and their multitude to man's singularity. The specific number of prostitutes listed in London (80,000 "actual human sacrifices on the altar of monogamy") draws particular attention to this point. If we refer to the schematic diagram, we can see how such an image counteracts and resolves $\$ 363$, whereby woman's suffering as a result of the necessity of her existence is absorbed into the idea that women's suffering-illustrated by the life of the prostitute - is rather a result of her surplus. On the other hand, the prostitute as a self-serving economic subject offers an important counter example to what Schopenhauer's previous claims over woman's abilities: the image of the prostitute remains an image of female sovereignty in terms of the transference of sexual activity to economics. Schopenhauer, though, is conspicuously quiet as to the economics of prostitution itself, and this is the important point when we consider how the prostitute relies economically on the "weapons" he has 


\section{THE LIMITS OF MISOGYNY}

previously described, rather than giving them up in marriage. It is noticeable that Schopenhauer terms the prostitute a "sacrifice on the alter of monogamy": that a position where the woman-image he had thus presented is empowered relative to the man is subsumed into a moral context of marriage; that a point of sovereignty, on Schopenhauer's own terms, that takes from the male subject is presented instead as an act of giving up. The prostitute only becomes a suitable image for the argument if the female has already been denied the possibility of a subject position.

The image of the prostitute is ensured to remain in a passive relation to the male subject because of the shift in emphasis of the essay, after $\$ 369$, from moral agency to economic sovereignty. This shifting of emphasis is key to Schopenhauer's authorial assertion over the interpretative possibilities of such a woman. In \$371, woman's “weak power of reasoning” is not related to her moral ineptitude at this point, but to her economic extravagance (which, Schopenhauer declares, was probably responsible for downfall of Louis XIII and starting of the French Revolution).

At all events, a false position of the female sex, such as has its most acute symptom in our lady-business, is a fundamental defect of the state of society. Proceeding from the heart of this, it is bound to spread its noxious influence to all parts. ${ }^{37}$

Here, the possibility of woman's economic sovereignty is not denied, but readily admitted through recourse to history-it is woman's occupation of sovereign roles that damages the state.

A popular, but misleading, reading of Schopenhauer's misogyny needs mentioning here. This reading links his views on women directly to his troubled economic relationship with his mother, whom he claimed spent a proportion of his inheritance on frivolous indulgences. The biographical image of the mother can, in turn, be supplemented by similar figures of women whom Schopenhauer was held in an economic imbalance. ${ }^{38}$ It follows, for these readings, that "On Women" is based on a reaction against allowing such women economic capability which results in the subject's loss. The problem with this approach is to oversimplify the structure of authority by which Schopenhauer limits his representation of woman's economic capability. Reducing Schopenhauer's argument to a relatively straightforward biographical allegory precludes any recognition of the disporia between the two images of "woman" that are necessary for such an economic exclusion to take place within the argument. Furthermore, as Hübscher argues, it is also historically questionable. True, there are undeniable similarities between the image of the

37 PPII, 626.

38 One usually thinks here of the story of the unfortunate elderly woman whom Schopenhauer discovered in his rented apartment, "gossiping" with his landlady. The enraged Schopenhauer attacked the woman, inflicting injuries that required him to pay her a pension for twenty years until she died. 
"European Lady" who destroys culture in "On Women," and the recurring image Schopenhauer presents of his mother in his journals. But Hübscher also points out that these same journals reveal many other affectionate but unremarkable relationships Schopenhauer shared with women, ${ }^{39}$ many of which are left unaccounted for by such a reductive allegorical reading of Schopenhauer's misogyny.

On my reading, we should rather focus on the conjunction of Schopenhauer's term "lady-business" with his earlier reference to women who exhibit a "professional jealousy" of each other. Clearly, some alignment is taking place between the two examples of "failed" subjects- the one moral and general, the other specific and historical. Thus, it is key that at the point where the pre-subjective image develops to a state of possible subjectivity in \$369, it is the secondary, post-subjective woman-image that instead emerges: because of which, the image of woman's economic sovereignty in $\$ 371$ is not, in fact, capable of 'sovereignty," but rather an image of excess unchecked. Unlike the early stages of the essay, there are no begrudging compliments to woman's potential virtues: her "value," after $\$ 369$, is solely in terms of a negation of the male subject. Furthermore, this economic limiting on the image of woman is an objectification of the excessive image: no longer, at this point, do women "compete" with each other to their detriment. Rather, they are a generic threat to man's value. Hence, the prostitute is not sovereign, but a failed wife, because she has already passed over the possibility of developing a subject position of her own. Consequently, the authorial subject re-establishes itself firmly in terms of the threat the economically sovereign woman poses.

\section{Conclusion}

At first, it may seem that we have not come too far with our reading. Schopenhauer is still a misogynist, as the fleeting references suggested before our close reading. Indeed, it was never the purpose of this paper to suggest otherwise, but rather to argue two points. First, that we cannot ignore Schopenhauer's misogyny as "unsystematic" and thus irrelevant without attending to both the rhetorical strengths and weaknesses of his argument. Second, there is an important discussion to be had based on this concerning not only the origin, motive and style of Schopenhauer's work, but the validity of interpretation itself of such motives and styles-perhaps not only in Schopenhauer's corpus, but the history of misogyny as well. I will elaborate on these points in more detail through a final consideration of Hübscher's reading. Hübscher's interpretation of "On Women" offers a number of challenges to the more traditional view of Schopenhauer as a misogynist. They can perhaps be summarised as covering three main areas: the legitimacy of "On Women" as a site of proper understanding of Schopenhauer's misogyny; the rationality of "On Women" as a philosophical argument; and the contestability of Schopenhauer's biography as an explanatory feature of interpretation.

${ }^{39}$ Hübscher, op cit., 190-1. 


\section{THE LIMITS OF MISOGYNY}

Hübscher's conclusions are as clear as they are provocative: that "On Women" does not provide the best account of Schopenhauer's views on sex, which is far more egalitarian than has been allowed for; that, nevertheless, the essay is a rational argument targeting the wrongs of the Romanticist ideal of "woman"; and that a fuller understanding of Schopenhauer's life reveals him to be, while certainly no Casanova, far from the ascetic tyrant often depicted. Indeed, Hübscher suggests that it is not "On Women," but the "Metaphysics of Sexual Love" in the second volume of The World as Will and Representation which provides Schopenhauer's most rounded view of the opposite sex.

The reading I have presented here takes further issue with these areas of interpretation. Rather than dismiss the notion of Schopenhauer as a misogynist, my aim has been to show that "On Women" provides a sophisticated philosophical argument against the moral and economic rights of women. To this end, it provides us with an insight into Schopenhauer's philosophy which the "Metaphysics of Sexual Love" does not: in that essay, "man" and "woman" are already in a set relation to each other, a relation which "On Women" provides the philosophical justification for. In On the Basis of Morality, too, Schopenhauer describes women as ethical agents, but agents who almost automatically fail the demands of ethics due to their lack a strong faculty for reasoning. Women's involvement in ethical deliberation is doomed because of Schopenhauer's (here ungrounded) image of woman's propriety: "injustice and deceitfulness are the most frequent vices of women, and lies are their proper element." 40 The importance of attending to the structure of "On Women" is precisely to analyse the philosophical grounding of all of Schopenhauer's representations of women, rather than choosing some, perhaps more immediately palatable images, over others. In recognising the structure of his argument, one is in a far better position to assess whether or not the misogynist "tag" is as fitting or stable as has sometimes been presumed, and whether Schopenhauer's account is a closed book with regards the possibilities of its interpretation.

Underlying "On Women," though, is Schopenhauer's representation of the authorial subject and it's "Other." The issue for the interpretation of such a text is therefore inextricable concerned with the reproduction of such representations within interpretative literature. Hübscher concludes that a more detailed account of Schopenhauer's life is necessary for an understanding of his views on woman, a view echoed in much of the contemporary scholarship. But this would seem only to maintain these same problems of the bio-allegorical method encountered above. Supplementing Schopenhauer's general comments on women with a specific historical figure is also internally inconsistent as an interpretative method: while the contemporary political problem of "woman" has proffered the full support of the Schopenhauer

40 The full quote is: "Owing to the weakness of their reasoning faculty, they are far less capable than men of understanding and sticking to universal principles, and of taking them as a guide. Hence injustice and deceitfulness are the most frequent vices of women, and lies are their proper element." A. Schopenhauer, On the Basis of Morality, trans. by E. J. Payne (Cambridge, Hackett Publishing Company, 1995), 151. 
biography, there has been little effort, for example, to relate the literal sense of economic imbalance in Schopenhauer's life to the monetary metaphors that recur throughout Schopenhauer's works. Such an explanation would also, presumably, have to justify every "unbalanced" moment within Schopenhauer's corpus in terms of a specific biographical event. More importantly, the biographical approach moves the focus of the interpretation away from the "unbalanced" style of writing that focuses exclusively on the authorial subject position as the site of study: that is to say, the importance of "schopenhauer" to Schopenhauer's work. In this sense, while Hübscher's critique of the anomalies in the secondary literature is of the utmost importance, we should not simply reject such anomalies outright as worthless to the study of Schopenhauer's authorship. Rather, given that the rhetoric of "On Women" is centred on the relationship between subject and non-subject, my suggestion is that any account of Schopenhauer's misogyny needs also to note that previous interpretations and references to Schopenhauer, however brief, are nevertheless responses to a particular construction of Schopenhauer's authority as a subject within the text. It is necessary to pay closer attention to such constructions of authority, not only if one is to understand a text's misogynistic arguments, but also to isolate the limits of such misogyny.

Department of Philosophy, Lancaster University, United Kingdom

\section{References}

Atwell, J., Schopenhaner on the Character of the World (London: University of California Press, 1995).

Bailey Saunders, T., Schopenhauer (London: Adam \& Charles Black, 1901).

Beer, M., Schopenhauer (London: T.C. \& E.C. Jack, 1914).

Hamlyn, D.W., Schopenhauer (London: Routledge \& Kegan Paul Ltd., 1980).

Hübscher, A., "Schopenhauer und die Weiber," in Schopenhauer Jabrbuch (1977), 187-203.

Janaway, C., "Introduction," in The Cambridge Companion to Schopenhauer (Cambridge: Cambridge University Press, 1999), 1-17.

Kamuf, P., Signature Pieces (London: Cornell University Press, 1988).

Mann, T., "Presenting Schopenhauer," in Schopenhauer: His Philosophical Achievement (Sussex: The Harvester Press, 1980), 3-19.

Oppel, F., Nietzsche on Gender (London: University of Virginia Press, 2005).

Schopenhauer, A., The World as Will and Representation Vol. II, trans. by E. J. Payne (New York: Dover Publications Inc., 1969). , Parerga and Paralipomena Vol. II, trans. by E. J. Payne (Oxford: Clarendon Press, 1974). , Sämtliche Werke, $4^{\text {th }}$ edition (Mannheim: F.A. Brockhaus, 1988). , On the Basis of Morality, trans. by E. J. Payne (Cambridge, Hackett Publishing Company, 1995).

Zimmern, H., Arthur Schopenhauer: His Life and Philosophy (London: Longmann Green \& Co., 1876). 